\title{
Climate and Nothofagus pumilio Establishment at Upper Treelines in the Patagonian Andes
}

\begin{abstract}
Ana M. Srur ${ }^{1 *}$, Ricardo Villalba ${ }^{1}$, Milagros Rodríguez-Catón ${ }^{1}$, Mariano M. Amoroso ${ }^{2,3}$ and Eugenia Marcotti ${ }^{1,4}$

${ }^{1}$ Instituto Argentino de Nivología, Glaciología y Ciencias Ambientales, CCT CONICET Mendoza, Mendoza, Argentina, 2 Instituto de Investigaciones en Recursos Naturales, Agroecología y Desarrollo Rural, Sede Andina, Universidad Nacional de Río Negro, Bariloche, Argentina, ${ }^{3}$ CCT CONICET Patagonia Norte, Bariloche, Argentina, ${ }^{4}$ Instituto de Ecorregiones Andinas CONICET-UNJu, Universidade Nacional de Jujuy, San Salvador de Jujuy, Argentina
\end{abstract}

The upper treeline provides a unique opportunity for documenting changes in forest dynamics in the context of current environmental fluctuations. Documenting the response of forests to present environmental changes will be very useful in developing and validating vegetation models that predict plant responses to global changes resulting from human activities. It is generally suggested that the expansion of the upper treeline is limited by cold temperatures, so warmer conditions are expected to induce an advance of forests into alpine vegetation. Significant changes in temperature and precipitation

OPEN ACCESS

Edited by:

Marius Schaefer,

Universidad Austral de Chile, Chile

Reviewed by:

Zoltan Kern,

MTA Research Centre for Astronomy and Earth Sciences, Hungary

Olga Nikolaevna Solomina, Institute of Geography (RAS), Russia

${ }^{*}$ Correspondence: Ana M. Srur asrur@mendoza-conicet.gob.ar

Specialty section: This article was submitted to Cryospheric Sciences, a section of the journal Frontiers in Earth Science

Received: 22 January 2018 Accepted: 07 May 2018 Published: 29 May 2018

Citation:

Srur AM, Villalba $R$, Rodríguez-Catón M, Amoroso MM and Marcotti E (2018) Climate and Nothofagus pumilio Establishment at Upper Treelines in the Patagonian Andes. Front. Earth Sci. 6:57. doi: 10.3389/feart.2018.00057 have already been documented in regional studies along the Patagonian Andes during the last decades. Across Patagonia, there are strong relationships between changes in climate and variations in the Southern Annular Mode (SAM). The atmospheric circulation indexes, act as climate packages summarizing climatic information since they combine changes in environmental variables. In order to complement previous studies in the northern Patagonia treeline, we have conducted a this study in the southern Patagonian Andes to: (1) characterize the patterns of Nothofagus pumilio establishment in the upper treeline along a precipitation gradient, (2) to establish the relationship between variations in regional climate and tree establishment and (3) to determine the influence of continental and hemispheric-scale climatic forcing on tree establishment at regional scale. Our studies suggest that the location of the upper treeline of the N. pumilio forest in the Patagonian Andes is sensitive to changes in climate variations. The temperature increment has facilitated the tree recruitment, however, the rate of seedling establishment appears to be more strongly modulated by the interaction between temperature increase and variations in precipitation. The expansion of the upper treeline has been limited to $5-10 \mathrm{~m}$ from the abrupt treeline. This comparatively reduced advance of the forest in the alpine grassland is regulated by other biotic and abiotic factors rather than the temperature increase. While the recent expansion of the upper treeline in northern Patagonia was regulated by temperature and precipitation variations associated with the different phases of the Pacific Decadal Oscillation, the establishment above the upper treeline in the southern Patagonian Andes was facilitated by climatic variations induced by the positive trend of the SAM during the last decades.

Keywords: establishment, upper treeline, treeline dynamics, Southern Annular Mode, Pacifical Decadal Oscillation, temperature, precipitation 


\section{INTRODUCTION}

The upper altitudinal limit of the forest is exposed to extreme environmental conditions. Small fluctuations in this environment determine changes in the patterns of tree establishment and mortality, which in turn alter forest distribution. Therefore, the upper treeline provides a unique opportunity for documenting changes in forest dynamics in the context of current environmental fluctuations. Indeed, the advance of new trees within and even above the upper treeline, as well as the increase in growth of trees, can be considered as reliable indicators of the forest's responses to changes in environmental conditions (Holtmeier and Broll, 2005). Documenting the response of forests to present environmental changes will be very useful in developing and validating vegetation models that predict plant responses to global changes resulting from human activities.

Several studies suggest that the expansion of the upper treeline is limited by cold temperatures, so warmer conditions are expected to induce an advance of forests into alpine vegetation (Tranquilini, 1979; Jobbagy and Jackson, 2000; Grace et al., 2002; Camarero and Gutiérrez, 2004; Körner and Paulsen, 2004; among others). Daubenmire's pioneering studies (Daubenmire, 1954) indicated that the forest's altitudinal limit coincided with the isotherm of $10^{\circ} \mathrm{C}$ during the warmest month of the year. More recently, Körner (1998) proposed a thermal threshold of 5.5$7.5^{\circ} \mathrm{C}$ during the growing season for the growth and development of plant tissues of tree species living in the upper boundary of the forest. Although temperature appear to be the main factor controlling the upper elevational limit of the forest, not all treelines reacts similarly to variations in temperature. On a global scale, warmer temperatures are not always associated with treeline advances (Harsch et al., 2009). Differences in treeline responses to global temperature increase may reflect distinct rates of temperature increases between regions (Trenberth et al., 2014) or treeline responses to different seasonal (spring vs. summer) temperature variations (Körner and Paulsen, 2004; Harsch et al., 2009). In addition, treeline responses can be asynchronous with temperature changes, either due to delays in physiological processes or growth activation after overpassing heating thresholds (Rupp et al., 2001; Renwick and Rocca, 2015).

In a global review, Harsch et al. (2009) reported that treelines have advanced in 52\% of the studied sites and remaining stable or unchanged in the rest, with the exception of one site in recession. Differences in responses would indicate that besides temperature, other environmental factors control treeline location. For example, interspecific interactions play an important role in controlling treeline dynamics (Spasojevic et al., 2013; Tingstad et al., 2015; Liang et al., 2016; Saccone et al., 2017; among others). Warming in the Tibetan Plateau has increased shrub density, which in turn slowed tree establishment above the treeline (Liang et al., 2016). Studies of tree colonization on recent moraines in southern Patagonia, show that Nothofagus pumilio mostly established in sectors covered by biological soil crust and/or creeping shrubs dominated by Empetrum rubrum (Pissolito, 2016). Other authors argued that factors such as wind and blowing ice modulate the carbon balance of individuals, and consequently the production of woody tissues (Stevens and Fox, 1991). The cold-induced photoinhibition appears also to regulate the germination and survival of new individuals (Danby and Hik, 2007). These interactions would act by masking or weakening the relationship between temperature increments and treeline rises.

According to Holtmeier and Broll (2005) the importance of different factors in regulating forest line dynamics depends on the spatial scale of the study and the speed of response of individuals to environmental changes to which they are exposed. These authors propose that on a global scale, the factors controlling treeline are macro-climatic factors, such as temperature and/or precipitation. However, at regional scale, inter-annual or seasonal climatic variability are more important (Holtmeier and Broll, 2005). At the site scale, microclimatic relationships such as wind exposure, duration of snow cover, soil type, human impact among others, are the dominant factors (Holtmeier and Broll, 2005).

In recent years have significantly increased the number of studies documenting the progress and retreat of treelines in the ecotones between forest and alpine vegetation or tundra (Kirdyanov et al., 2012; Elliott and Cowell, 2015; Franke et al., 2017; Jochner et al., 2017; among others). Most treelines are characterized by gradual transitions between the forest and the alpine vegetation. This transition is characterized by forest patches that increase the heterogeneity of the site and favor the establishment of new individuals (Spasojevic et al., 2013, 2014). The upper limit of the forest in the Patagonian Andes is dominated by species of Nothofagus trees displaying an abrupt limit between the forest and the grasslands, without a gradual transition of patches or isolated individuals toward the high Andean vegetation (Figure 1; Cuevas, 2000; Daniels and Veblen, 2003; Harsch et al., 2012; Srur et al., 2016). Therefore, it is very likely that the establishment and survival of new individuals will be more difficult in abrupt rather than transitional ecotones between the forest and the upper Andean vegetation.

Significant changes in temperature and precipitation have already been documented in regional studies along the Patagonian Andes during the last decades (Masiokas et al., 2008, 2009; Falvey and Garreaud, 2009). According with the last IPCC report, a precipitation decrease concurrent with a temperature increase of $0.1^{\circ} \mathrm{C}$ per decade has been recorded since 1960 in southern Chile and adjacent Argentina (Magrin et al., 2014). Across Patagonia, there are strong relationships between changes in climate (temperature and precipitation) and variations in the Southern Annular Mode (SAM or Antarctic Oscillation; Garreaud, 2009; Garreaud et al., 2009; Moreno et al., 2014). SAM is the main mode of variability of tropospheric circulation in the extra-tropical region of South America, characterized by pressure anomalies of opposite sign in the sub-Antarctic region $\left(60-65^{\circ} \mathrm{S}\right)$ and in the temperate band at $\sim 40-50^{\circ} \mathrm{S}$ (Garreaud et al., 2009). Positive correlations between SAM and temperature throughout Patagonia $\left(40^{\circ}-54^{\circ} \mathrm{S}\right)$ and negative correlations with zonal wind intensity and precipitation north of $50^{\circ} \mathrm{S}$ during summer have been documented from climate analyses (Marshall, 2003; Villalba et al., 2012; Moreno et al., 2014).

The atmospheric circulation indexes such as SAM, act as climate packages summarizing climatic information since 


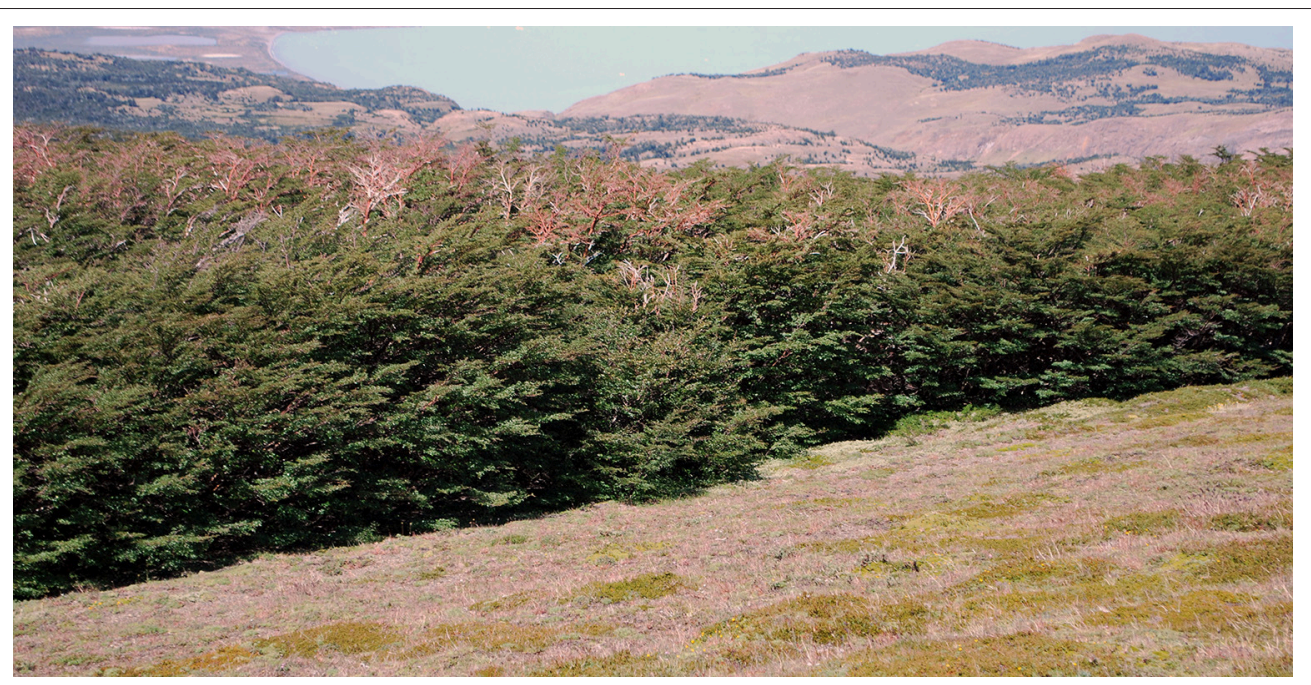

FIGURE 1 | Abrupt treeline in the El Chaltén. Picture taken by Ricardo Villalba in the 2016-2017 summer.

they combine changes in precipitation, temperature, wind, evaporation, among other environmental variables. The use of these indices allows us to reduce the spatial and temporal complexity of climate variables and to determine relationships with biotic processes in areas where climate data are scarce (Stenseth et al., 2003). Although changes in the atmospheric circulation indexes do not directly affect treeline dynamics, variations in SAM, or other circulation indexes, are related to anomalies in the temperature or/and precipitation, which in turn affect treeline advances or retreats (Woodward et al., 1995; Daniels and Veblen, 2003; Wang et al., 2006; Astudillo-Sánchez et al., 2017). Indeed, a recent study in the Northern Andes of Patagonia indicates that the establishment of Nothofagus in the upper treeline is markedly regulated by regional climatic variations associated with phase changes in the Pacific Decadal Oscillation (Srur et al., 2016).

There are larger uncertainty about future climate changes in southern Patagonia, however, the registered increase in temperature concomitant with the dominant glacier retreat are expected to continue or even intensified during the twentyfirst century (Magrin et al., 2014). Changes in environmental conditions can lead to loss of biodiversity, changes in the demography and distribution of species, and consequently alter the structure and composition of communities (Hansen et al., 2001; Bellard et al., 2012; Mainali et al., 2015). Therefore, studying forest dynamics in the areas exposed to climate change, such as treeline, is relevant to understanding how future climate will affect the functioning of ecosystems and the services that they provide to humans.

In order to complement previous studies documenting the climatic influences on tree establishment in the northern Patagonia treeline, we have conducted a similar study in the southern Patagonian Andes to: (1) characterize the patterns of $N$. pumilio establishment in the upper treeline along a precipitation gradient, (2) to establish the relationship between variations in regional climate and tree establishment, and (3) to determine the influence of continental and hemispheric-scale climatic forcing on tree establishment at regional scale. Finally, the results from this study in the southern Patagonian Andes will be compared with those from the northern Patagonia to establish differences and similarities in the patterns of tree establishment at the upper treeline and their relationships with climate.

\section{MATERIALS AND METHODS}

\section{Study Area}

The study area is situated along the Río de las Vueltas basin in the Santa Cruz province, Argentina, from El Chaltén village to Lago del Desierto (Figure 2). The whole region is under the strong influence of the persistent Westerlies throughout the year (Villalba et al., 2003; Garreaud et al., 2009, 2013). The Andes acts as a barrier to the humid air masses coming from the Pacific inducing an important west-east precipitation gradient (Villalba et al., 2003). The temperature of the region is influenced by both latitude and altitude, the average temperature described for the area is $6^{\circ} \mathrm{C}$ (Villalba et al., 2003).

Forests in the area belong to the sub-Antarctic phytogeographic province, Deciduous Forest District and are dominated by $N$. pumilio (Cabrera, 1976). From the lower part of the forest and up to 800-950 m, well-developed and erect $N$. pumilio individuals vary between 10 and $20 \mathrm{~m}$ in height (Boelcke et al., 1985). On the contrary, individuals are smaller in the highest parts of the forest and become stunted near the upper boundary. As the snow load increases with elevation, typical 6-8 $\mathrm{m} \mathrm{L}$-shaped individuals give way to multi stem krummholz at the upper edge of the forest.

At El Chaltén ( $400 \mathrm{~m}$ a.s.l.), located in the forest-steppe ecotone, the total annual precipitation is $\sim 550 \mathrm{~mm}$, evenly distributed throughout the year. Mean annual temperature at this locality is close to $7^{\circ} \mathrm{C}$ (data provided by Los Glaciares National Park, period 1992-2001). At 1,100 m a.s.l. in the upper treeline, the period covered by snow is of $\sim 140$ days per year, 


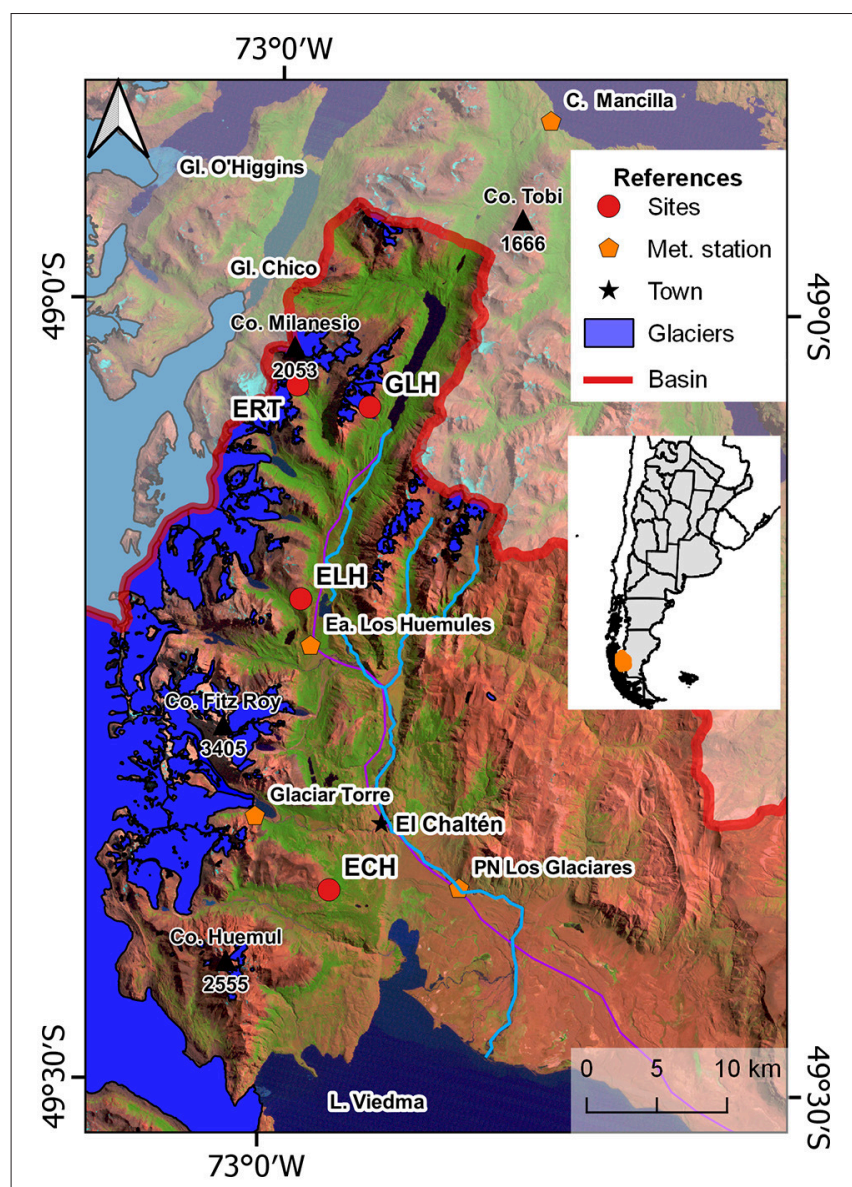

FIGURE 2 | Location of the sample sites along the precipitation gradient. For more details regarding the sampling sites, refer to Table $\mathbf{1 .}$

extending from the beginning of June to middle November (period 2004-2013, data from IANIGLA). At the mesic sector in the Estancia Los Huemules, $17 \mathrm{~km}$ in northwest direction from from El Chaltén, the total annual precipitation is above $1,000 \mathrm{~mm}$ and the mean annual temperature reaches $6^{\circ} \mathrm{C}$ (period 20072012). At the wet sector of the precipitation gradient, total annual rainfalls are above $2,000 \mathrm{~mm}$. Although our record for Estancia Río Toro is short (less than a year), total annual precipitation at the close meteorological station of Cerro Mansilla $(309 \mathrm{~m})$ is around 2,400 $\mathrm{m}$. Cerro Mansilla is located $52 \mathrm{~km}$ to the north of El Chaltén and just $27 \mathrm{~km}$ from our sites at the wet extreme of the precipitation gradient.

Four study sites were established along the southeastnorthwest precipitation gradient in the Río de las Vueltas basin (Table 1; Figure 2). At the driest treeline site on Pliegue Tumbado, slopes are gentle with E-SE orientation. The density of seedling above treeline exceeds 40 individuals per hectare with mean height and basal diameter of 8 and $1.1 \mathrm{~cm}$, respectively (Table 1, Figure 3A). On the mesic sector, the upper treeline is located on gentle to middle slopes facing the SE. Here, the density is larger than 18 individuals per hectare. This site recorded the smallest individuals both in height and diameter (Table 1,
TABLE 1 | Geographic location and characteristics of sample sites.

\begin{tabular}{|c|c|c|c|c|}
\hline & El Chaltén & $\begin{array}{l}\text { Estancia Los } \\
\text { Huemules }\end{array}$ & $\begin{array}{l}\text { Glaciar } \\
\text { Huemul }\end{array}$ & $\begin{array}{l}\text { Estancia } \\
\text { Río Toro }\end{array}$ \\
\hline Code & $\mathrm{ECH}$ & ELH & GLH & ERT \\
\hline Latitude ${ }^{\circ} \mathrm{S}$ & 49.38 & 49.20 & 49.07 & 49.06 \\
\hline Longitude ${ }^{\circ} \mathrm{W}$ & 72.94 & 72.99 & 72.91 & 72.98 \\
\hline Elevation $\mathrm{m}$ asl & 1,073 & 1,053 & 993 & 1,027 \\
\hline Slope $\left({ }^{\circ}\right)$ & 9.6 & 23 & 26 & 35 \\
\hline Aspect & E-SE & SE & S-SE & $E$ \\
\hline Soil type & Molisols & Molisols & Molisols & Molisols \\
\hline Characteristic & Dry treeline & Mesic treeline & Wet treeline & Wet treeline \\
\hline Density (ind/ha) & 41.96 & 18.49 & 153.05 & 8.86 \\
\hline Height (mm) & 83.7 & 79.0 & 98.6 & 143.3 \\
\hline $\begin{array}{l}\text { Basal diameter } \\
(\mathrm{mm})\end{array}$ & 11.6 & 2.5 & 6.8 & 9.8 \\
\hline Mean age (years) & $\begin{array}{c}12.18 \\
(1.64) \mathrm{a}\end{array}$ & $14.53(1.29) \mathrm{a}$ & $12.79(0.89) \mathrm{a}$ & $9.8(1.78) \mathrm{a}$ \\
\hline $\begin{array}{l}\text { Mean distance } \\
\text { to treeline }(\mathrm{m})\end{array}$ & $5.88(0.37) \mathrm{a}$ & $11.84(0.40) b$ & $3.14(0.11) \mathrm{c}$ & $4.8(0.33) \mathrm{a}$ \\
\hline
\end{tabular}

For mean age and distance to treeline, the standard errors are displayed in parentheses. Different letters show statistically significant differences at $p \leq 0.05$.

Figure 3B). Finally, at the wettest treelines (Figures 3C,D), seedling density is extremely variable between sites (Table 1). At the Estancia Río Toro treeline, individuals are taller and growing on steep slopes (Table 1; Figure 3D).

\section{Fieldwork and Laboratory Methods}

Four study sites were established along the precipitation gradient from the relative dry forest-steppe ecotone in El Chaltén to the humid Laguna del Desierto in the upper sector of the Río de las Vueltas basin. Sampling was conducted during the austral summers from 2004-2005 to 2010-2011. Two to four rectangular plots were established at each of four sites, extending from the local treeline up to the alpine grasses (Table 1, Figure 3). In each plot, we measured the distance between the new individuals and the continuous treeline. In order to determine the year of tree establishment, increment cores were taken as close to the root collar as possible using increment borers. Individuals with a basal diameter $<3 \mathrm{~cm}$ were cut at the root collar, and their cross-sections sliced in the laboratory using a sliding microtome. At El Chaltén (ECH), Glacial Huemul (GLH), and Estancia Río Toro (ERT) sites, 187, 62 and 51 individuals were sampled, respectively. In Estancia Los Huemules (ELH), the site showing the highest tree density, we randomly sampled 1 of each 4 individuals from a total of 122 samples. Increment borer samples were mounted on wooden mounts and subsequently polished. All samples were processed and dated following the standard dendrochronology technique proposed by Stokes and Smiley (1968). For cores that did not reach the pith, the missing rings were estimated following Villalba and Veblen (1997).

\section{Analysis}

The establishment patterns in the treeline were analyzed taking into account the age of the individuals and the distance 


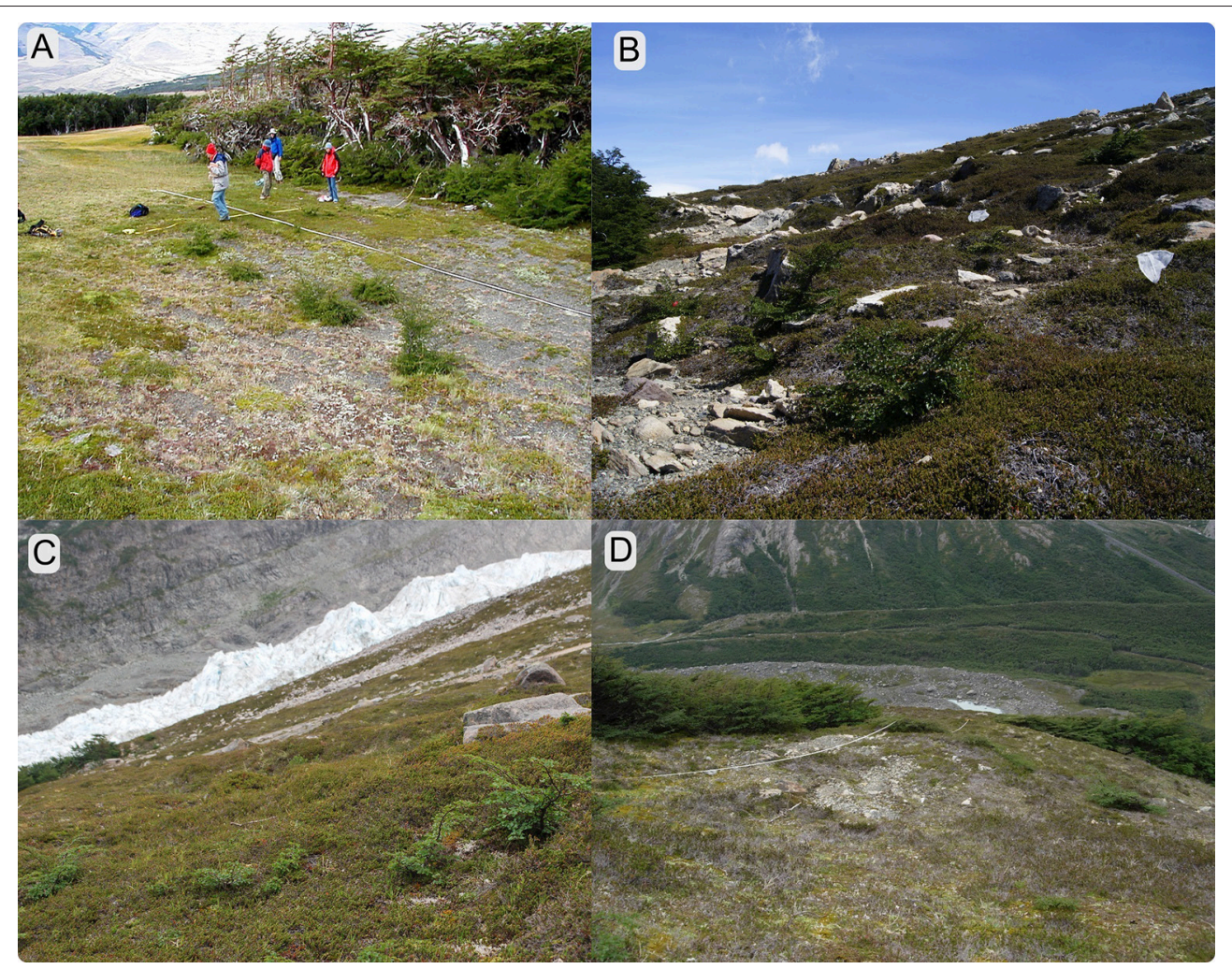

FIGURE 3 | Tree establishment above the Nothofagus abrupt treelines at the sampling sites. (A) El Chalten, (B) Estancia Los Huemules, (C) Glaciar Huemul, and (D) Estancia Rio Toro.

of the seedling to the treeline. Differences in the distance between individuals and treelines between sites were evaluated using the non-parametric $U$-test of Mann-Whitney (Zar, 1999).

Temperature and precipitation records in the Río de las Vueltas basin are short and fragmentary. Therefore, we used in the comparisons between climate and tree establishment the records from Punta Arenas, representing the most extent and complete series of temperature and precipitation for the region. The climate data was downloaded from the website of the Chilean Meteorological Directorate (http://www.meteochile.gob.cl/PortalDMC-web/index.

xhtml).

The Niño 3.4, PDO and SAM Marshal indexes were obtained, respectively, from:

http://www.cgd.ucar.edu/cas/catalog/climind/TNI_N34/

index.html (access date 8 September 2016)

http://research.jisao.washington.edu/pdo/PDO.latest (access date 20 June 2016)

http://www.nerc-bas.ac.uk/public/icd/gjma/newsam.1957. 2007.txt (access date 03 March 2017)

Using the ffcsaps function of the dplR package (Bunn et al., 2016), interannual variations in establishment, temperature and precipitation were smoothed using spline funtions.

\section{RESULTS}

Mean ages from the individuals established above upper treeline showed no significant differences between sites (dry, mesic, and humid) along the precipitation gradient from El Chaltén to Laguna del Desierto (Table 1). However, the mean distance from the edge of the forest at which new individuals are established, showed significant differences between sites (Table 1). Whereas the ELH and GLH sites showed the largest and smallest distance from the continuous forest line, respectively, the sites at the extremes of the gradient (ECH and ERT) showed intermediate values and not significant differences between them (Table 1).

The rate of $N$. pumilio establishment over time followed similar patterns at the different sites along the precipitation gradient (Figure 4). In general, the establishment patterns presented a bimodal distribution characterized by a gradual increase in the number of individuals since the mid-1970s, peaking in the late 1980s-early 1990s and again around the year 2000. This particular pattern is reinforced when tree establishment is evaluated at regional level (Figure 4). However, it should be noted some temporary differential response in tree establishment between wet and dry sites. Whereas at the wettest site (ERT) the maximum establishment peak took place in the most recent period, at the driest sites (ECH and ELH) the establishment was more abundant in the earliest period. 


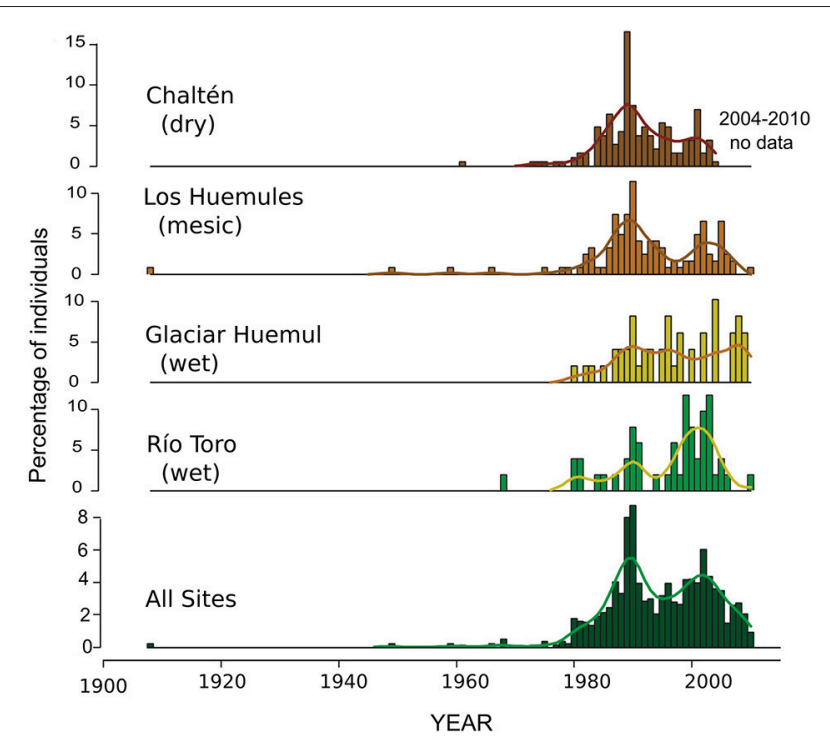

FIGURE 4 | Frequency distribution of individuals established at the upper-treeline sites. Sampling sites ordered from the driest (top) to the wettest (bottom) along El Chalten-Laguna del Desierto precipitation gradient. The regional establishment is shown at the bottom. Smoothed versions of the establishment temporal distributions estimated using a 10-year cubic spline function are also shown.

The temporal pattern of Nothofagus establishment in the treeline appear to be influenced by climatic variability (Figure 5). Both peaks in the temporal distribution of the establishment are related to summer temperature increases, while the decrease in recent years is concurrent with a marked reduction in summer precipitation (Figure 5).

\section{DISCUSSION}

The upper treeline from N. pumilio in the southern Patagonian Andes is sensitive to variations in climate. The increment in summer temperatures recorded between the cold interval 19661977 (mean $=9.6^{\circ} \mathrm{C}$ ) to the prevailing warmer period from 1978 to present $\left(\right.$ mean $=10.34^{\circ} \mathrm{C}$ ) has favored the establishment and survival of new individuals above the upper treeline. Old photographs from the region indicate that the upper treeline has remained quite stable at least for seven decades since the beginning of the twentieth century to the mid-1970s. Along the El Chaltén-Lago del Desierto precipitation gradient, all selected sites showed seedling establishment above treeline. However, it is important to note that local site conditions, such as steep slopes and/or lack of herbaceous cover, strongly inhibit the Nothofagus seedling establishment on the upper treeline. Our results are consistent with previous studies documenting a treeline advance during the past decades related to temperature increases since the mid-1970s in many sites along the Patagonian Andes (Daniels and Veblen, 2004; Srur et al., 2004, 2016).

The Nothofagus recruitment above the upper treeline started at mid-1970 and continues until today, albeit with differences in the patterns of establishment rates. At the dry-mesic sectors in the transect, the tree establishment that started in the mid-1970 following the temperature increment, peaked in the late 1980s, coincident with abundant summer precipitations from 1988 to 1994 . The temporal changes in establishment rates at these sites indicated that tree establishment and survival at dry-mesic treelines is also modulated by amount of soil water available for growth. On the contrary, above-average precipitation in the wet treelines prolongs the snow cover duration and significantly reduce the extent of the growing season. A more attenuated peak in tree establishment occurred at the end of the 1980's in the wet sectors in comparison with that recorded at the drier sites along the precipitation transect. At the wet Estancia Río Toro site, the largest rate of recruitment were centered around the year 2000, concurrent with warmer summers recording normal precipitation (Figure 4). In consequence, our observations reveal important interactions between temperature and establishment modulated by precipitation. The establishment of new individuals in the dry upper treelines requires warmer temperatures accompanied by abundant precipitations to ensure the survival of the recent established plants. In humid environments, the higher temperatures that act reducing the permanence of snow, increase the duration of the growing season, and consequently, facilitate the establishment of new individuals in the upper treeline.

The dynamics of the Nothofagus treeline has also been investigated in New Zealand (Harsch et al., 2012). With morphological characteristics similar to the Nothofagus forests in Patagonia, forest expansion in the New Zealand upper treeline appears to be limited mainly by the scarcity of suitable microsites for seedling establishment. Therefore, the authors suggest that treelines in New Zealand appears to be less sensitive to recent global warming, and consequently, unlikely to show substantial upward movement under the current low demographic rates recorded at high elevations. Our results for Patagonia show, on the contrary, that treelines dominated by $N$. pumilio are sensitive to temperature changes, but other abiotic changes such as precipitation appears to play a key role in tree establishment. Poor-developed soils with extremely low water capacity, provides extremely adverse conditions to seedling colonization in southern Patagonia (Pissolito, 2016). Whereas warmer temperatures could lead to increases in tree establishment, abundant precipitation would contribute to the survival of seedling, particularly in the dry and mesic environments of the Patagonian upper treeline (Daniels and Veblen, 2004; Srur et al., 2016).

At the wet treelines in the rainy Chilean sector, Piper et al. (2013) also noted that warming has favored the establishment of $N$. pumilio seedlings in the southern Andes, however, they highlighted the importance of site-specific conditions in modulating the response of tree dynamics to climate change. They argued that heat-induced water deficits do not cancel out the benefits of higher temperatures for Nothofagus seedling survival and growth. Comparatively, the results from Piper et al. (2013) are consistent with those recorded at our wetter sites, since the increase in temperature in the early 2000's, concurrent with normal precipitation, favored establishment at the wet but 


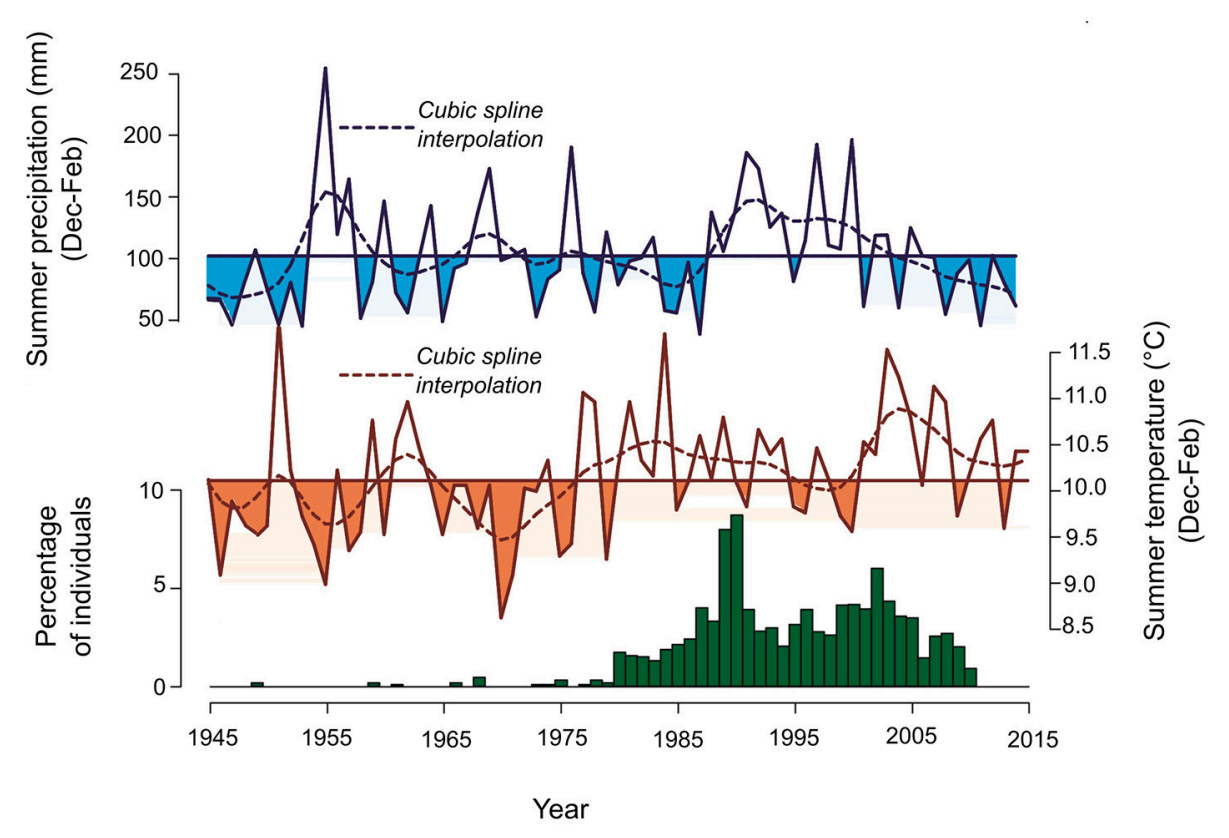

FIGURE 5 | Temporal variations in regional seedling establishment at the upper treelines in southern Patagonia and in Punta Arenas summer (December to February) temperature and precipitation. Straight lines represent the summer temperature and precipitation means. Smoothed versions of establishment and climatic variations using a cubic spline function of 10 years are also shown (dashed line).

not at the dry treelines. At the rainy treelines, precipitation is enough to compensate the increase in evapotranspiration due to higher temperatures. However, the long-term negative trend in precipitation since 2000 seems to have affected establishment in both wet and dry upper forests along the Río de las Vueltas basin (Figure 5). The scarce recruitment recorded in the last decade is in line with studies reporting the negative effects of warming on $N$. pumilio establishment due to the more severe water deficits recently recorded in the dry Patagonian Andes from Argentina (Heinemann et al., 2000; Daniels and Veblen, 2003; Srur et al., 2016).

In the Patagonian Andes, as well as in New Zealand, tree dynamics at the upper treeline has also been related to Nothofagus seed production and dispersal. Indeed, masting events have been reported for N. pumilio in Tierra del Fuego (Cuevas, 2000, 2002). Although two recruitment peaks are recorded at regional scale, they are not observed at most individual sites (Figure 4). Unfortunately, our records of seed production and seedling survival for the region are short, and therefore, not able of reliably detecting masting events. Therefore, the importance of long-term studies to properly answer relevant dynamics process in the treeline are evident. For the Chilean rainy treelines, Piper et al. (2013) reported an increase in seed production but not peaks in tree establishment, suggesting that an increase in Nothofagus seed production not necessarily reflect higher recruitment rates. For the Nothofagus treelines in New Zealand, Richardson et al. (2005) documented an increment in seed production over the past 30 years but not a concomitant recruitment increase over the same period (Harsch et al., 2012).
Another topic of discussion in relation to forest expansion deals with the distance between new establishment and the location of the current treeline. Most studies agree that the distance between new seedlings and the treeline depend on forest location and intensity of prevailing winds. Wind protected sites by tree barriers, windward slopes or large outcrops facilitate the establishment of seedlings through the creation of safe sites (Holtmeier and Broll, 2007; McIntire et al., 2016). Upper treelines in Patagonia are affected by the strong westerly winds all year round (Villalba et al., 2003; Garreaud et al., 2009), which certainly influence the dispersal of $N$. pumilio seeds. The longest distance recorded between new individuals and the continuous treeline was of $11.84 \mathrm{~m}$ at the forest leeward in Estancia Los Huemules. Therefore, and in accordance with other authors, not only the temperature increase modulates the treeline progression but also other abiotic factors existing at the site. Recent studies suggest that N. pumilio seed is comparatively heavy in the context of wind dispersed trees, being particularly the heaviest of all seeds within the genus Nothofagus in South America (Urretavizcaya et al., 2016). The $N$. pumilio seed is 9 times heavier than $N$. dombeyi's and 11 times than $N$. antartica' s (Urretavizcaya et al., 2016). This characteristics of $N$. pumilio seed may also explain why tree establishment always occurs nearby the forest (Rusch, 1993). In general, the establishment is limited to $5 \mathrm{~m}$ from the tree line, even when appropriate microsites may be available at greater distances. Similarly, Harsch et al. (2012) noted that Nothofagus recruitment in New Zealand is mostly limited to the proximity to the forest. Therefore, the rate of Nothofagus treeline expansion is not only modulated by changes in temperature. Biotic and abiotic factors other than temperature 
also modulate the rhythm of treeline progression into upper alpine vegetation.

Variations in temperature and precipitation at the southern end of South America are largely modulated by changes in the phases of the South Annular Mode (SAM; Falvey and Garreaud, 2009; Garreaud et al., 2009). The positive phase of SAM, characterized by anomalies of high atmospheric pressure in medium latitudes, is related to elevated temperatures and reduced precipitation in the Patagonian Andes (Marshall, 2003; Garreaud et al., 2009; Villalba et al., 2012). In particular, the positive trend in the SAM since the late 1950s is consistent with the rise in temperatures in the region. For the period 1957-2015 (59 years) the variations in the average annual temperature of Punta Arenas are significantly related to SAM $(r=0.46, p<0.001$; Figure 6). Consequently, the process of treeline expansion in our region in response to rising temperatures is finally a response to the positive trend observed in the SAM since the early 1960s (Figure 6). Relationships between SAM and precipitation in the Southern Patagonian Andes are more difficult to assess given the complexity of precipitation patterns introduced by the Andes Mountains and the lack of long and reliable meteorological records. The relationship between the annual precipitation of Punta Arenas and SAM is not statistically significant over the common period 1957-2015, but it is during the last 30 years. For the period
1986-2015, the positive trend in the SAM has contributed to the decrease in total annual precipitation in Punta Arenas since the early 1990s $(r=-0.52 ; p<0.003)$. As noted above, the increase in temperature since the mid-1970s has facilitated the establishment of new individuals in the upper treeline. However, the temporary rhythm of establishment has been partly modulated by variations in precipitation, particularly summer rainfall in the drier treelines. The steady decline in precipitation over the last few decades would be responsible for the slower rhythm of establishment in recent years. This situation would be affecting the establishment and/or survival of seedlings in both dry and wet sites along the precipitation gradient of Río Las Vueltas basin.

Similar to what has been documented in this paper, the increase in spring-summer temperature of $0.5^{\circ} \mathrm{C}$ in northern Patagonia facilitated the establishment of new individuals over the upper limit of the forest (Srur et al., 2016). However, this increase in temperature that occurred in the 1976/77 climate jump was associated with the documented phase change, from negative to positive, of the Pacific Decadal Oscillation (PDO). In its return to the negative phase of PDO at the beginning of the twenty-first century (Trenberth et al., 2014; Vuille et al., 2015), the climate in northern Patagonia became more variable, with spring-summer temperatures similar to those recorded in the negative phase of PDO prior to
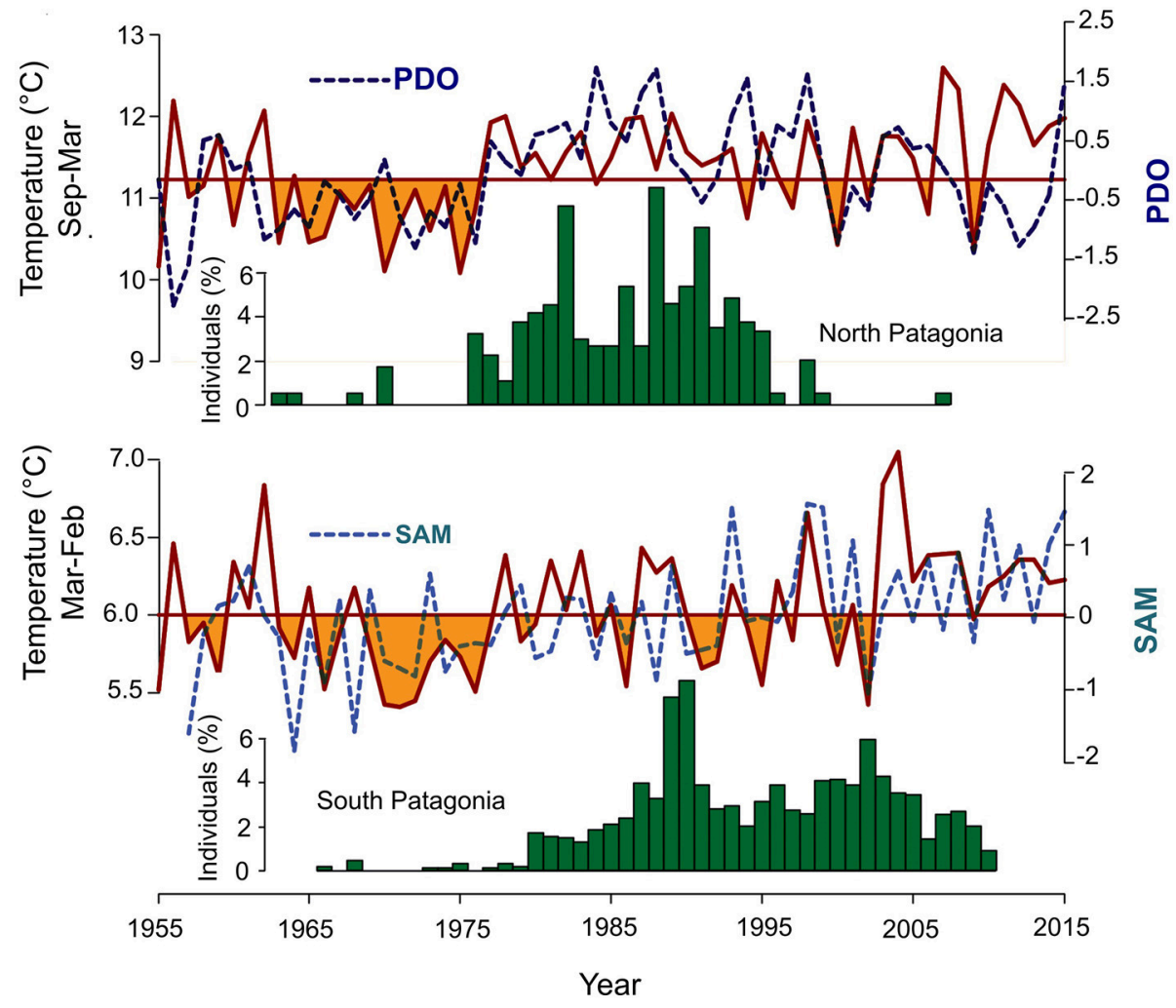

FIGURE 6 | Comparison between tree establishment above upper treelines in northern and southern Patagonia and their relationships with temperature and the associated atmospheric circulation indices. Temperature plotted with continuous line, PDO and SAM represented with dashed line. 
1976. In particular, the establishment on the treeline in northern Patagonia follows more closely the variations in the PDO phases than in temperature changes (Figure 6). Indeed, Stenseth et al. (2003) argue that atmospheric circulation indices integrate a set of environmental variables beyond those that could be reflected in a single climatic variable such as temperature. The negative PDO phase is associated with lower temperatures, but also with lower precipitation in northern Patagonia (Srur et al., 2016). It is probably the combined occurrence of colder spring-summer and lower precipitation that has reduced or silenced the establishment of Nothofagus specimens on the abrupt treeline in northern Patagonia.

Similarly, the establishment of Nothofagus on treeline in the Southern Patagonian Andes seems to be more strongly regulated by SAM's influence on temperature and precipitation regimes. The sustained increase in temperature associated with the persistence of the positive phase of SAM since the mid-1970's has facilitated establishment over treeline, but variations in establishment rates seem to be associated with variations in regional precipitation also influenced by SAM. In particular, the lack of establishment over the last few years in the Southern Patagonian Andes would be a response to the reduction in regional precipitation, as temperatures have remained at levels similar to those recorded since the mid-1970s.

\section{CONCLUSIONS}

Our studies suggest that the location of the upper treeline of the N. pumilio forest in the Patagonian Andes is sensitive to changes in climate variations. The recorded increments in regional temperature have facilitated the establishment and therefore the ascent of the upper treeline. However, the regional expansion of the treeline is extremely variable when it is evaluated at local scale. Site topography, exposure and soil development, among other factors, markedly influence $N$. pumilio tree establishment at local scale in the upper treeline. The temperature increment has facilitated the tree recruitment in both the dry-mesic and wet treelines along the precipitation gradient in Río de las Vueltas basin. However, the rate of seedling establishment appears to be more strongly modulated by the interaction between temperature increase and variations in precipitation. In the dry to mesic sites of the upper treeline, the survival of the seedlings depends on the occurrence of wet periods, whereas wet periods prolong the snowpack cover in the wet treelines limiting tree establishment. Finally, prolong droughts affect tree establishment at both dry and humid treelines on the Argentinean slopes of the southern Andes.

The expansion of the upper treeline in the Patagonian Andes has been limited to $5-10 \mathrm{~m}$ from the abrupt treeline. This comparatively reduced advance of the forest in the alpine grassland is regulated by other biotic and abiotic factors rather than the temperature increase. The location of the sites in relation to prevailing winds, microsite conditions, and the comparatively heavy seeds of $N$. pumilio (up to 9-11 times the seed weight of other Nothofagus seeds) affects the spatial advance of the upper treeline.

While the recent expansion of treeline in northern Patagonia was regulated by temperature and precipitation variations associated with the different phases of PDO, the climatic variations induced by the persistently positive trend of SAM during the last decades were what facilitated the establishment in the Southern Patagonian Andes. In both cases, the rhythm of establishment in the upper treeline responded to interactions between temperature and precipitation rather than to variations in only one of these meteorological variables. The scarce precipitation associated with the negative phase of PDO in the north and with the positive phase of SAM in the southern Patagonian Andes seems to have reduced establishment in recent years. Conversely, temperature increases in response to the positive phases of both PDO and SAM from the 1970s onwards triggered the establishment process at the upper boundary of the forest.

Despite the high value of retrospective studies such as the one presented here, the need for long-term monitoring of forest dynamics in treeline areas is evident. These studies would allow us to clarify basic aspects of the population dynamics of the species in these climate change-sensitive sites, such as variability in seed production or seedling mortality rates, providing us with more information about the effects that such change may have on the future distribution of forests and the ecosystem services they provide.

\section{AUTHOR CONTRIBUTIONS}

AS and RV participated in the development of all the paper (field work, data analysis and writing). MR-C participated in fieldwork, data analysis and paper review. MA participated in the fieldwork and review of the paper. EM analyzed some of the data and reviewed the work.

\section{ACKNOWLEDGMENTS}

This study was partially supported by CONICET, Argentina. The authors would like to thank Alberto Ripalta, Claudia Guerrido, Mariano Masiokas, and Silvia Delgado for field work assistance. The authors would also like to thank the owners and administrators of Estancia Río Toro (José María Barale and Ricardo Sanchez) and of Estancia Los Huemules (Federico Reese). On the other hand, we would also like to thank you for the permits granted by the administration of national parks, especially Los Glaciares section. Lidia Ferri and Pierre Pitte provided useful comments on the manuscript. 


\section{REFERENCES}

Astudillo-Sánchez, C. C., Villanueva-Díaz, J., Endara-Agramont, A. R., NavaBernal, G. E., and Gómez-Albores, M. A. (2017). Climatic variability at the treeline of Monte Tlaloc, Mexico: a dendrochronological approach. Trees 31, 441-453. doi: 10.1007/s00468-016-1460-z

Bellard, C., Bertelsmeier, C., Leadley, P., Thuiller, W., and Courchamp, F. (2012). Impacts of climate change on the future of biodiversity. Ecol. Lett. 15, 365-377. doi: 10.1111/j.1461-0248.2011.01736.x

Boelcke, O., Moore, D. M., and Roig, F. A. (1985). Transecta Botánica de la Patagonia Austral. Buenos Aires: Consejo Nacional de Investigaciones Cientificas y Tecnicas.

Bunn, A., Korpela, M., Biondi, F., Campelo, F., Mérian, P., Qeadan, F., et al. (2016). dplR: Dendrochronology Program Library in $R$. Available online at: http://CRAN.R-project.org/package $=$ dplR

Cabrera, A. L. (1976). Regiones Fitogeográficas Argentinas. Enciclopedia Argentina de Agricultura y Jardinería. Buenos Aires: Acme.

Camarero, J. J., and Gutiérrez, E. (2004). Pace and pattern of recent treeline dynamics: response of ecotones to climatic variability in the Spanish Pyrenees. Clim. Change 63, 181-200. doi: 10.1023/B:CLIM.0000018507.71343.46

Cuevas, J. G. (2000). Tree recruitment at the Nothofagus pumilio alpine timberline in Tierra del Fuego, Chile. J. Ecol. 88, 840-855. doi: $10.1046 / j .1365-2745.2000 .00497 . x$

Cuevas, J. G. (2002). Episodic regeneration at the Nothofagus pumilio alpine timberline in Tierra del Fuego, Chile. J. Ecol. 90, 52-60. doi: 10.1046/j.0022-0477.2001.00636.x

Danby, R. K., and Hik, D. S. (2007). Evidence of recent treeline dynamics in southwest Yukon from aerial photographs. Arctic 60, 411-420.

Daniels, L. D., and Veblen, T. T. (2003). Altitudinal treelines of the southern Andes near $40^{\circ}$ S. For. Chron. 79, 237-241. doi: 10.5558/tfc79237-2

Daniels, L. D., and Veblen, T. T. (2004). Spatiotemporal influences of climate on altitudinal treeline in northern Patagonia. Ecology 85, 1284-1296. doi: 10.1890/03-0092

Daubenmire, R. (1954). Alpine timberlines in the Americas and their interpretation. Butl. Univ. Bot. Stud. 11, 119-136.

Elliott, G. P., and Cowell, C. M. (2015). Slope aspect mediates fine-scale tree establishment patterns at upper treeline during wet and dry periods of the 20th century. Arct. Antarct. Alp. Res. 47, 681-692. doi: 10.1657/AAAR0014-025

Falvey, M., and Garreaud, R. D. (2009). Regional cooling in a warming world: recent temperature trends in the southeast Pacific and along the west coast of subtropical South America (1979-2006). J. Geophys. Res. 114, 1-16. doi: 10.1029/2008JD010519

Franke, A. K., Bräuning, A., Timonen, M., and Rautio, P. (2017). Growth response of Scots pines in polar-alpine tree-line to a warming climate. For. Ecol. Manag. 399, 94-107. doi: 10.1016/j.foreco.2017.05.027

Garreaud, R. D. (2009). The Andes climate and weather. Adv. Geosci. 22, 3-11. doi: 10.5194/adgeo-22-3-2009

Garreaud, R. D., Vuille, M., Compagnucci, R., and Marengo, J. (2009). Present-day South American climate. Palaeogeogr. Palaeoclimatol. Palaeoecol. 281, 180-195. doi: 10.1016/j.palaeo.2007.10.032

Garreaud, R., Lopez, P., Minvielle, M., and Rojas, M. (2013). Large-scale control on the Patagonian climate. J. Clim. 26, 215-230. doi: 10.1175/JCLI-D-12-00001.1

Grace, J., Berninger, F., and Nagy, L. (2002). Impacts of climate change on the tree line. Ann. Bot. 90, 537-544. doi: 10.1093/aob/mcf222

Hansen, A. J., Neilson, R. P., Dale, V. H., Flather, C. H., Iverson, L. R., Currie, D. J., et al. (2001). Global change in forests: responses of species, communities, and biomesinteractions between climate change and land use are projected to cause large shifts in biodiversity. Bioscience 51, 765-779. doi: 10.1641/00063568(2001)051[0765:GCIFRO]2.0.CO;2

Harsch, M. A., Buxton, R., Duncan, R. P., Hulme, P. E., Wardle, P., and Wilmshurst, J. (2012). Causes of tree line stability: stem growth, recruitment and mortality rates over 15 years at New Zealand Nothofagus tree lines. J. Biogeogr. 39, 2061-2071. doi: 10.1111/j.1365-2699.2012.02763.x

Harsch, M. A., Hulme, P. E., McGlone, M. S., and Duncan, R. P. (2009). Are treelines advancing? A global meta-analysis of treeline response to climate warming. Ecol. Lett. 12, 1040-1049. doi: 10.1111/j.1461-0248.2009. 01355.x
Heinemann, K., Kitzberger, T., and Veblen, T. T. (2000). Influences of gap microheterogeneity on the regeneration of Nothofagus pumilio in a xeric oldgrowth forest of northwestern Patagonia, Argentina. Can. J. For. Res. 30, 25-31. doi: $10.1139 / \mathrm{x} 99-181$

Holtmeier, F.-K., and Broll, G. (2005). Sensitivity and response of northern hemisphere altitudinal and polar treelines to environmental change at landscape and local scales. Glob. Ecol. Biogeogr. 14, 395-410. doi: 10.1111/j.1466-822X.2005.00168.x

Holtmeier, F.-K., and Broll, G. (2007). Treeline advance - driving processes and adverse factors. Landsc. Online 1, 1-33. doi: 10.3097/LO.200701

Jobbagy, E. G., and Jackson, R. B. (2000). Global controls of forest line elevation in the northern and southern hemispheres. Glob. Ecol. Biogeogr. 9, 253-268. doi: 10.1046/j.1365-2699.2000.00162.x

Jochner, M., Bugmann, H., Nötzli, M., and Bigler, C. (2017). Among-tree variability and feedback effects result in different growth responses to climate change at the upper treeline in the Swiss Alps. Ecol. Evol. 7, 7937-7953. doi: $10.1002 /$ ece3.3290

Kirdyanov, A. V., Hagedorn, F., Knorre, A. A., Fedotova, E. V., Vaganov, E. A., Naurzbaev, M. M., et al. (2012). 20th century tree-line advance and vegetation changes along an altitudinal transect in the Putorana Mountains, northern Siberia: 20th century tree-line advance, N Siberia. Boreas 41, 56-67. doi: 10.1111/j.1502-3885.2011.00214.x

Körner, C. (1998). Re-assessment of high elevation treeline positions and their explanation. Oecologia 115, 445-459. doi: 10.1007/s004420050540

Körner, C., and Paulsen, J. (2004). A world-wide study of high altitude treeline temperatures. J. Biogeogr. 31, 713-732. doi: 10.1111/j.1365-2699.2003.01043.x

Liang, E., Wang, Y., Piao, S., Lu, X., Camarero, J. J., Zhu, H., et al. (2016). Species interactions slow warming-induced upward shifts of treelines on the Tibetan Plateau. Proc. Natl. Acad. Sci. U.S.A. 113, 4380-4385. doi: 10.1073/pnas.1520582113

Magrin, G. O., Marengo, J. A., Boulanger, J. P., Buckeridge, M. S., Castellanos, E., Poveda, G., et al. (2014). "Central and South America," in Climate Change 2014: Impacts, Adaptation, and Vulnerability. Part B: Regional Aspects. Contribution of Working Group II to the Fifth Assessment Report of the Intergovernmental Panel on Climate Change (Cambridge, UK; New York, NY: Cambridge University Press), 1499-1566.

Mainali, K. P., Warren, D. L., Dhileepan, K., McConnachie, A., Strathie, L., Hassan, G., et al. (2015). Projecting future expansion of invasive species: comparing and improving methodologies for species distribution modeling. Glob. Change Biol. 21, 4464-4480. doi: 10.1111/gcb.13038

Marshall, G. J. (2003). Trends in the Southern Annular Mode from observations and reanalyses. J. Clim. 16, 4134-4143. doi: 10.1175/1520-0442(2003)016<4134:TITSAM>2.0.CO;2

Masiokas, M. H., Luckman, B. H., Villalba, R., Delgado, S., Skvarca, P., and Ripalta, A. (2009). Little ice age fluctuations of small glaciers in the Monte Fitz Roy and Lago del Desierto areas, South Patagonian Andes, Argentina. Palaeogeogr. Palaeoclimatol. Palaeoecol. 281, 351-362. doi: 10.1016/j.palaeo.2007.10.031

Masiokas, M. H., Villalba, R., Luckman, B. H., Lascano, M. E., Delgado, S., and Stepanek, P. (2008). 20th-century glacier recession and regional hydroclimatic changes in northwestern Patagonia. Glob. Planet. Change 60, 85-100. doi: 10.1016/j.gloplacha.2006.07.031

McIntire, E. J. B., Piper, F. I., and Fajardo, A. (2016). Wind exposure and light exposure, more than elevation-related temperature, limit tree line seedling abundance on three continents. J. Ecol. 104, 1379-1390. doi: 10.1111/1365-2745.12599

Moreno, P. I., Vilanova, I., Villa-Martínez, R., Garreaud, R. D., Rojas, M., and De Pol-Holz, R. (2014). Southern annular mode-like changes in southwestern Patagonia at centennial timescales over the last three millennia. Nat. Commun. 5: 4375. doi: 10.1038/ncomms5375

Piper, F. I., Fajardo, A., and Cavieres, L. A. (2013). Simulated warming does not impair seedling survival and growth of Nothofagus pumilio in the southern Andes. Perspect. Plant Ecol. Evol. Syst. 15, 97-105. doi: 10.1016/j.ppees.2013.02.003

Pissolito, C. (2016). Sucesión Primaria de la Vegetación en Bosques de Nothofagus spp. en los Andes Patagónicos: Patrones Espacio-Temporales de Establecimiento de Plantas e Implicancias Para la Restauración. Ph.D. Dissertation, Universidad Nacional de Cuyo, Mendoza. 
Renwick, K. M., and Rocca, M. E. (2015). Temporal context affects the observed rate of climate-driven range shifts in tree species: importance of temporal context in tree range shifts. Glob. Ecol. Biogeogr. 24, 44-51. doi: 10.1111 /geb.12240

Richardson, S. J., Allen, R. B., Whitehead, D., Carswell, F. E., Ruscoe, W. A., and Platt, K. H. (2005). Climate and net carbon availability determine temporal patterns of seed production by Nothofagus. Ecology 86, 972-981. doi: 10.1890/04-0863

Rupp, T. S., Chapin, F. S., and Starfield, A. M. (2001). Modeling the influence of topographic barriers on treeline advance at the foresttundra ecotone in northwestern Alaska. Clim. Change 48, 399-416. doi: 10.1023/A:1010738502596

Rusch, V. E. (1993). Altitudinal variation in the phenology of Nothofagus pumilio in Argentina. Rev. Chil. Hist. Nat. 66, 131-141.

Saccone, P., Hoikka, K., and Virtanen, R. (2017). What if plant functional types conceal species-specific responses to environment? Study on arctic shrub communities. Ecology 98, 1600-1612. doi: 10.1002/ecy.1817

Spasojevic, M. J., Bowman, W. D., Humphries, H. C., Seastedt, T. R., and Suding, K. N. (2013). Changes in alpine vegetation over 21 years: are patterns across a heterogeneous landscape consistent with predictions? Ecosphere 4, 1-18. doi: 10.1890/ES13-00133.1

Spasojevic, M. J., Harrison, S., Day, H. W., and Southard, R. J. (2014). Above- and belowground biotic interactions facilitate relocation of plants into cooler environments. Ecol. Lett. 17, 700-709. doi: 10.1111/ele. 12272

Srur, A. M., Villalba, R., Rodríguez-Catón, M., Amoroso, M. M., and Marcotti, E. (2016). Establishment of Nothofagus pumilio at upper treelines across a precipitation gradient in the Northern Patagonian Andes. Arct. Antarct. Alp. Res. 48, 755-766. doi: 10.1657/AAAR00 16-015

Srur, A. M., Villalba, R., Villagra, P. E., Morales, M. S., and Lana, N. B. (2004). "Estructura y dinámica del bosque de Nothofagus pumilio a lo largo de un gradiente altitudinal en El Chaltén, Santa Cruz," in II Reunión Binacional de Ecología. XI Reunión de la Sociedad de Ecología de Chile y XXI Reunión Argentina de Ecología (Mendoza).

Stenseth, N. C., Ottersen, G., Hurrell, J. W., Mysterud, A., Lima, M., Chan, K. S., et al. (2003). Studying climate effects on ecology through the use of climate indices: the North Atlantic oscillation, El Nino Southern oscillation and beyond. Proc. R. Soc. Lond. B. Biol. Sci. 270, 2087-2096. doi: $10.1098 /$ rspb.2003.2415

Stevens, G. C., and Fox, J. F. (1991). The causes of treeline. Annu. Rev. Ecol. Syst. 22, 177-191. doi: 10.1146/annurev.es.22.110191.001141

Stokes, M. A., and Smiley, T. L. (1968). An Introduction to Tree-Ring Dating. Chicago, IL; London: University of Chicago Press.

Tingstad, L., Olsen, S. L., Klanderud, K., Vandvik, V., and Ohlson, M. (2015). Temperature, precipitation and biotic interactions as determinants of tree seedling recruitment across the tree line ecotone. Oecologia 179, 599-608. doi: 10.1007/s00442-015-3360-0

Tranquilini, W. (1979). “General features of the upper timberline," in Physiological Ecology of the Alpine Timberline (Berlin; Heidelberg: Springer), 1-4.

Trenberth, K. E., Fasullo, J. T., Branstator, G., and Phillips, A. S. (2014). Seasonal aspects of the recent pause in surface warming. Nat. Clim. Change 4, 911-916. doi: $10.1038 /$ nclimate 2341

Urretavizcaya, M. F., Contardi, L. T., Oyharçabal, M. F., and Pasquini, M. (2016). Calidad de semillas de especies nativas del bosque andino patagónico de la provincia de Chubut y su importancia para la producción de plantines. Rev. Fac. Agron. Plata 115, 9-18. Available online at: http://hdl.handle.net/10915/ 54164

Villalba, R., Lara, A., Boninsegna, J. A., Masiokas, M., Delgado, S., Aravena, J. C., et al. (2003). Large-scale temperature changes across the southern Andes: 20th-century variations in the context of the past 400 years. Clim. Change 59, 177-232. doi: 10.1023/A:1024452701153

Villalba, R., Lara, A., Masiokas, M. H., Urrutia, R., Luckman, B. H., Marshall, G. J., et al. (2012). Unusual Southern Hemisphere tree growth patterns induced by changes in the Southern Annular Mode. Nat. Geosci. 5, 793-798. doi: 10.1038/ngeo1613

Villalba, R., and Veblen, T. T. (1997). Regional patterns of tree population age structures in Northern Patagonia: climatic and disturbance influences. J. Ecol. 85, 113-124. doi: 10.2307/2960643

Vuille, M., Franquist, E., Garreaud, R., Lavado Casimiro, W. S., and Cáceres, B. (2015). Impact of the global warming hiatus on Andean temperature. J. Geophys. Res. Atmospheres 120, 3745-3757. doi: 10.1002/2015JD023126

Wang, T., Zhang, Q.-B., and Ma, K. (2006). Treeline dynamics in relation to climatic variability in the central Tianshan Mountains, Northwestern China. Glob. Ecol. Biogeogr. 15, 406-415. doi: 10.1111/j.1466-822X.2006.00233.x

Woodward, A., Schreiner, E. G., and Silsbee, D. G. (1995). Climate, geography, and tree establishment in Subalpine Meadows of the Olympic Mountains, Washington, U.S.A. Arct. Alp. Res. 27, 217-225. doi: 10.2307/1551952

Zar, J. (1999). Biostatistical Analysis. Upper Saddle River, NJ: The University of Chicago Press.

Conflict of Interest Statement: The authors declare that the research was conducted in the absence of any commercial or financial relationships that could be construed as a potential conflict of interest.

Copyright (c) 2018 Srur, Villalba, Rodríguez-Catón, Amoroso and Marcotti. This is an open-access article distributed under the terms of the Creative Commons Attribution License (CC BY). The use, distribution or reproduction in other forums is permitted, provided the original author(s) and the copyright owner are credited and that the original publication in this journal is cited, in accordance with accepted academic practice. No use, distribution or reproduction is permitted which does not comply with these terms. 